\title{
ZAMYŠLENÍ NAD OZNAMOVACÍ POVINNOSTÍ PSYCHOLOGŮ JAKO PRACOVNÍKŮ V POMÁHAJÍCÍCH PROFESÍCH
}

\author{
Matěj Střiteský
}

\begin{abstract}
Abstrakt
Článek se zaměřuje na oznamovací povinnost pracovníků v pomáhajících profesích ohledně trestných činů, o nichž se dozví od svých klientů. Autor prezentuje otázku oznamovací povinnosti jako právní a etický problém. Součástí článku jsou i výsledky pilotního výzkumu, kterým autor zjištoval přehled českých psychologů o dané problematice. Autor dochází k závěru, že psychologové v ČR mají tendenci oznamovat více trestných činů, než jim ze zákona plyne, a prezentuje s tím související komplikace např. ve vztahu k povinné mlčenlivosti.
\end{abstract}

Klíčová slova: mlčenlivost, oznamovací povinnost, trestný čin

\section{THE REFLECTION ON THE NOTIFICATION DUTY OF PSYCHOLOGISTS AS WORKERS IN ASSISTING PROFESSIONS}

\begin{abstract}
The presented article focused on the notification duty of workers in helping professions on criminal activities of their clients. The author presents the notification duty as a legal and ethical issue. The article includes results of a pilot study on knowledge of psychologists about the notification duty. The author concludes that psychologists tend to report more criminal activities than the law requires. Possible complications connected with this reporting are discussed.
\end{abstract}

Key words: confidentiality, notification duty, crime

Došlo: 10. 8. 2017

Schváleno: 29. 11. 2017 


\section{Úvod}

Oznamovací povinnost je téma, které může u pracovníků v pomáhajících profesích pochopitelně vyvolávat rozpaky. V nejkonfliktnější situaci zde proti sobě stojí zájem klienta na neoznámení trestného činu a na druhé straně zájem profesionála na tom vyhnout se své kriminalizaci. V provedené pilotní studii jsme se českých psychologů a studentů psychologie ptali na jejich př́stup ke konkrétním př́padům, v nichž oznamovací povinnost přichází v úvahu. Cílem článku je iniciovat odbornou diskuzi o tomto v praxi se vyskytujícím problému.

Pro člověka, který si zvolil práci v pomáhající profesi, může být uvedený konflikt ohrožením sebepojetí, které můžeme popsat nap̌r. následovně: ,„Jsem přece ten, kdo klientưm pomáhá, a ne ten, kdo je udává “. V tomto článku se snažíme prezentovat informace, které mohou sloužit $\mathrm{k}$ řešení tohoto konfliktu. Před dalším čtením článku čtenáři navrhujeme, aby si pomocí dotazníku ${ }^{1}$ sám vyzkoušel, jak by se zachoval, kdyby byl konfrontován se situací, v níž přichází v úvahu naplnění či nenaplnění oznamovací povinnosti. Řešení př́ípadů z dotazníku je obsaženo v tomto článku.

\section{Co je oznamovací povinnost?}

Oznamovací povinnost znamená, že existují natolik závažné situace, pro něž nás právní řád zbavuje svobody mlčet, pokud se o nich dozvíme. Nenaplnění takové oznamovací povinnosti pak právní řád stíhá sankcí (Šámal, 2012). Povinnost oznámit určité skutečnosti najdeme v různých předpisech, např. zákon č. $361 / 200$ Sb., o provozu na pozemních komunikacích v $\$ 43$ odst. 3 písm. b) ukládá povinnost účastníkům nehody oznámit ji ve stanovených př́padech policii, zákon č. 133/ 1985 Sb., o požární ochraně v $§ 78$ odst. 1 ukládá povinnost oznámit požár a zákon č. 372/2011 o zdravotních službách ukládá v § 83 odst. 1 oznámit nález těla zemřelého mimo zdravotnické zařízení.

Oproti poněkud neobvyklým př́padům oznamovací povinnosti uvedeným výše je nutné se ještě před řešením otázky oznamovací povinnosti dle trestního zákoníku zaměřit na oznamovací povinnost podle $\S 10$ odst. 4 zákona č. 359/1999 Sb., o sociálně právní ochraně dětí $^{2}$. Tento zákon ukládá poskytovatelům zdravotních služeb ${ }^{3}$, mezi které spadají např. i psychologové ve zdravotnictví, bez zbytečného odkladu oznámit orgánu sociálně právní ochrany dětí, pokud se dozví o tom (nebo získá podezření), že na dítěti je páchán trestný čin. Takové oznámení pak není porušením mlčenlivosti. Nesplnění této povinnosti je naopak přestupkem a může za něj být uložena pokuta do výše 50.000 Kč. I když jde o sankci citelnou, je mnohem méně závažná než sankce, které mohou být ukládány podle trestního zákoníku, a nejedná se o přestupek, který by se zapisoval do rejstř́iku trestů. Blíže k oznamovací povinnosti v prípadě trestných činů páchaných na dětech viz článek (Mach, 2011). ${ }^{4}$

\footnotetext{
${ }^{1}$ https://goo.gl/forms/5XpxdnIyLlrYQKh42

${ }^{2}$ Viz: https://www.zakonyprolidi.cz/cs/1999-359\#p10-4

${ }^{3}$ Uvedené ustanovení povinnost ukládá i státním orgánům a školským zařízením, týká se tedy i školních psychologů a psychologů v PPP.

${ }^{4} \mathrm{http} / / /$ www.zdravotnicke-pravo.cz/0007-znasilneni-a-pohlavni-zneuziti-ditete-hlasit-ci-nehlasit
} 
Pro tento článek je však klíčová oznamovací povinnost vyplývající z § 368 zákona č. 40/2009 $\mathrm{Sb}$, trestního zákoníku ${ }^{5}$ (dále jen trestní zákoník). Uvedené ustanovení trestního zákoníku zavádí skutkovou podstatu neoznámení trestného činu. Uvedeného trestného činu se dopustí ten, kdo se hodnověrným způsobem dozví, že jiný spáchal vyjmenovaný trestný čin a takový trestný čin neoznámí. Za spáchání uvedeného trestného činu může být uložen trest odnětí svobody až na tři léta.

Vedle neoznámení trestného činu existuje trestný čin nepřekažení trestného činu, který upravuje $\S 367$ trestního zákoníku. Rozdíl mezi překažením a oznámením spočívá v tom, že oznamujeme to, co se již stalo, a překazujeme to, co se zrovna děje nebo se plánuje. Otázku překazovací povinnosti necháváme stát mimo rámec této práce, a to $\mathrm{z}$ důvodu, že překažení trestného činu považujeme za méně konfliktní otázku ${ }^{6}$, a zároveň jsme přesvědčeni, že pomáhající profese se o trestné činnosti dozvídají spíše po jejím spáchání než v jejím průběhu.

Oznamovací povinnost nedopadá na všechny trestné činy, ale jen na trestné činy výslovně vyjmenované v § 367 trestního zákoníku. Zde je vhodné zvýraznit, že smyslem uvedeného ustanovení není ulehčovat práci policii a nabádat obyvatele $\mathrm{k}$ udavačství, ale chránit „zájem společnosti na boji s nejzávažnější kriminalitou odhalováním a postihem nejzávažnějších trestných činů a jejich pachatelï“ (Šámal, 2012, s. 367). Z uvedeného vyplývá, že trestné činy, které jsou do oznamovací povinnosti zahrnuty svou závažností, patř́i mezi trestné činy závažné, nenajdeme mezi nimi tak časté ale méně závažné ${ }^{7}$ trestné činy jako je krádež, loupež, podvod nebo ublížení na zdraví (nikoliv těžké). Naopak mezi vyjmenovanými trestnými činy nalezneme i velmi neobvyklé trestné činy jako použití zakázaného bojového prostředku, vlastizradu a rozvracení republiky. Z trestných činů, s nimiž se pracovník v pomáhající profesi může ve své praxi pravděpodobně setkat a na které dopadá oznamovací povinnost, přichází v úvahu zejména vražda, těžké ublížení na zdraví a týrání svěřené osoby. Pokud tedy uvažujeme o oznamovací povinnosti, musíme mít na paměti, že se neoznamuje každý trestný čin, ale jen trestný čin určený zákonem.

\section{Jak je časté trestní stíhání za nesplnění oznamovací povinnosti?}

Oznamovací povinnost pracovníků v pomáhající profesi je zmiňována v téměř každé učebnici medicínského práva $^{8}$ (protože zdravotníci jsou nejtypičtějším představitelem pomáhající profese), je jí věnován prostor v kurzech etiky ${ }^{9}$, autoři o ní píší články a existují školení zaměřená výlučně na tuto otázku ${ }^{10}$, mohlo by se tak zdát, že se jedná o v praxi často řešenou

\footnotetext{
${ }^{5}$ https://www.zakonyprolidi.cz/cs/2009-40\#p368

${ }^{6}$ Protože zde kromě plnění zákonné povinnosti chráníme i společenskou hodnotu, která má být trestným činem teprve ohrožena, zatímco v případě oznamovací povinnosti už tato hodnota ohrožena byla a oznámení na tom nic nezmění. Další argument představuje i to, že překazit trestný čin můžeme i tím, že se ho pachateli pokusíme rozmluvit, pokud jsme přesvědčeni o úspěchu naší intervence, nejednáme trestně.

7 Závěry o četnosti páchaných trestných činů vychází ze statistického přehledu kriminality za rok 2015, dostupné na stránkách PČR zde: http://www.policie.cz/clanek/statisticke-prehledy-kriminalityza-rok-2015.aspx

${ }^{8}$ Viz např. Sovová (2011)

9 Viz např. kurz společnosti Persefona zde: http://www.persefona.cz/kurz-oznamovaci-povinnostvyplyvajici-z-trestniho-zakoniku-v-pardubicich

${ }^{10}$ Např. předmět Etika v psychologii vyučovaný na Filozofické fakultě MU v Brně
} 
situaci. Realita je však odlišná, dle statistických ročenek kriminality za rok 2013 a 2014 (Policie ČR, 2017) bylo za tento trestný čin za uvedené dva roky stíháno celkem sedm osob. Ačkoliv toto číslo není nijak vysoké, tak kriminalizace sedmi osob z pomáhajících profesí za neoznámení informací, které se dozvěděly od svých klientů, by byla nezanedbatelná. Pokud ale nahlédneme do rozsudků týkajících se řešeného trestného činu, tak zjistíme, že tento trestný čin páchají jiné osoby než osoby pracující v pomáhajících profesích. Níže uvádíme soudní rozhodnutí. Př́ípady v nich řešené považujeme za typické reprezentanty řešeného trestného činu.

- V rozhodnutí Vrchního soudu v Praze ze dne 13. 11. 1993, sp. zn. R 16/1994, byl řešen př́ipad muže $X$, který byl svědkem počátečního konfliktu mezi pachatelem Y a dvěma muži ozbrojenými noži, které pachatel Y posléze usmrtil údery barovou židlí. V rozhodnutí je řešeno, zda se X dopustil trestného činu neoznámení vraždy, nebo zda se nejednalo o vraždu $\mathrm{z}$ důvodu nutné obrany pachatele $\mathrm{Y}$.

- V usnesení Ústavního soudu ze dne 10. 2. 2011 sp. zn. II ÚS 44/08 ${ }^{11}$ byl řešen př́pad muže $\mathrm{X}$, který známé půjčil pistoli údajně za účelem ochrany před násilným manželem, ta mu ji později vrátila a posléze vyšlo najevo, že manžel známé byl zastřelen. Muž neoznámil, že známá měla k dispozici jeho zbraň a že jí pravděpodobně manžela zastřelila. Muž byl odsouzen za neoznámení trestného činu vraždy.

- V médiích (ČTK, 2009) byl řešen prrípad ředitele nemocnice, kterého orgány činné $\mathrm{v}$ trestním řízení podezíraly z toho, že měl vědět o tom, že jeden ze zaměstnancủ usmrcuje pacienty, ačkoliv ředitel zaměstnance propustil, nekontaktoval policii. Ředitel nemocnice byl osvobozen a dočkal se i omluvy od Ministerstva spravedlnosti.

Obdobně i nepřekažení trestného činu se typově dopouští jiní pachatelé než pracovníci v pomáhajících profesí. Pro ilustraci lze uvést např. situaci, kdy dojde k přepadení, kterému celou dobu určitá osoba pouze přihlíží a až po jeho dokončení zavolá zraněné přepadené pomoc $^{12}$, nebo situaci, kdy osoba přihlíží tomu, jak násilník svou obět' bije až do bezvědomí a rozhodne se zasáhnout až v okamžiku, kdy se násilník chystá obět' polít benzínem a zapálit ${ }^{13}$.

Bývají zmiňovány př́ípady sociálních pracovnic, které jsou stíhány za to, že neoznámily informace o týrání dítěte, toto jednání, však spíše naplňuje skutkovou podstatu trestného činu maření úkolu úřední osoby z nedbalosti dle $\S 330$ trestního zákoníku (Bořil, 2012). Snaha autora vyhledat př́ípad, v němž by byl pracovník v pomáhající profesi stíhán za nesplnění oznamovací povinnosti, byla neúspěšná. Pokud má čtenář informace o tom, že k takovému stíhání došlo, bude autor vděčný za zaslání takové informace.

Vidíme tak, že trestný čin neoznámení trestného činu není v praxi příliš často řešen a že i tyto ojedinělé př́ípady stíhají jiné pachatele než pracovníky v pomáhajících profesích.

\section{Př́pady z dotazníku}

Přes výše uvedené konstatování, že úvahám o kriminalizaci pracovníků v pomáhajících profesích za nesplnění oznamovací povinnosti je věnován značný prostor, náš pilotní výzkum ukázal, že psychologové, zapojení do dotazníkového šetření, nemají v dané problematice př́liš jasno.

\footnotetext{
${ }^{11}$ http://nalus.usoud.cz/Search/ResultDetail.aspx?id=69093\&pos=1\&cnt=1\&typ=result

12 Usnesení Nejvyššího soudu ze dne 19. 6. 2013, sp. zn. 8 Tdo 554/2013

${ }^{13}$ Usnesení Nejvyššího soudu ze dne 30. 9. 2003, sp. zn. 6 Tdo 1017/2003
} 
Dotazník byl tvořen šesti popisy situací, kdy psycholog stojí před rozhodnutím, zda policii oznámit či neoznámit jednání, o němž se dozvěděl od klienta. Situace byly vybrány napříč různými psychologickými povoláními a byly konzultovány v rámci doktorského semináře na Filozofické fakultě MU. Dotazník byl velektronické podobě šířen mezi psychology a studenty psychologie. Ke dni psaní tohoto článku dotazník zodpovědělo 42 respondentů (11 mužů), 15 respondentů již bylo aktivními v praxi a studenti tvořící zbytek souboru nejčastěji byli ve 4. ročníku. Dotazník se zaměřuje i na to, jak si psychologové své rozhodování o oznamovací povinnosti zdůvodňují, nicméně tato data doposud nebyla zpracována.

\section{Niže prezentujeme jednotlivé př́pady $v$ dotazníku}

V prvním př́ípadě byla popsána situace klientky, která $\mathrm{v}$ průběhu terapie uvede, že byla znásilněna. Z dotazníkového šetření vyplynulo, že 23,3 \% dotazovaných je přesvědčeno, že v takovém prŕípadě mají povinnost nahlásit znásilnění na policii. Znásilnění není uvedeno mezi trestnými činy uvedenými v $§ 386$ trestního zákoníku a oznamovací povinnost, zde tak není dána.

V druhém př́padě byla popsána situace stejné klientky, která násilníka ve zkratovitém jednání přejela autem, čímž ho usmrtila. Jedná se o trestný čin zabití. Z dotazníkového šetření vyplynulo, že 84,4 \%, dotazovaných je přesvědčeno, že v takovém př́ípadě mají povinnost nahlásit zabití na policii. Zabití není uvedeno mezi trestnými činy uvedenými v $§ 386$ trestního zákoníku a oznamovací povinnost zde tak není dána.

Ve třetím př́ípadě byla popsána situace, kdy mladistvý odcizil sbírku vzácných mincí a zmíní se o tom psychologovi. Z dotazníkového šetření vyplynulo, že 53,5\% dotazovaných je přesvědčeno, že v takovém př́ípadě mají povinnost nahlásit odcizení mincí policii. Mezi trestnými činy uvedenými v $§ 386$ trestního zákoníku není uveden žádný, pod který by bylo možné odcizení mincí podřadit, a oznamovací povinnost zde tak není dána.

Ve čtvrtém př́ípadě byla popsána situace, kdy se psycholog dozví, že jedno dětí v kolektivu je terčem závažné šikany. Z dotazníkového šetření vyplynulo, že $30 \%$ dotazovaných je přesvědčeno, že v takovém př́ípadě mají povinnost hlásit šikanu policii. Mezi trestnými činy uvedenými v $\S 386$ trestního zákoníku není uveden žádný, pod který by bylo možné chování dětí podřadit, a oznamovací povinnost zde tak není dána.

V pátém prŕípadě byla popsána situace, kdy otčím, který je aktuálně ve výkonu trestu odnětí svobody, dříve pohlavně zneužíval nezletilého. $Z$ dotazníkového šetření vyplynulo, že $72,1 \%$ dotazovaných je přesvědčeno, že $v$ takovém př́ípadě mají povinnost hlásit pohlavní zneužívání policii. Mezi trestnými činy uvedenými v § 386 trestního zákoníku není uvedeno pohlavní zneužívání, a oznamovací povinnost zde tak není dána.

$\mathrm{V}$ šestém př́ípadě byla popsána situace, kdy se vězeňský psycholog dozví, že spoluvězeň vězně, který s psychologem hovoří, měl v průběhu hospodské rvačky způsobit někomu vážnou újmu na zdraví a nebyl za to nikdy stíhán. $Z$ dotazníkového šetření vyplynulo, že $41,19 \%$ dotazovaných je prresvědčeno, že v takovém př́padě mají povinnost hlásit těžké ublížení na zdraví policii. Mezi trestnými činy uvedenými v $\$ 386$ trestního zákoníku těžké ublížení na zdraví nalezneme, oznamovací povinnost je zde tak dána za předpokladu, že psycholog vězni uvěří. 
Na základě provedeného šetření konstatujeme, že psychologové, kteří dotazník zodpověděli, jsou přesvědčeni, že mají povinnost oznamovat i takové trestné činy, které zákon oznamovat neukládá. Psychologové jsou tak často mylně přesvědčeni, že musí narušit vztah důvěry s klientem, kvưli neexistující právní povinnosti.

\section{Je oznámení vz̆dy bezpečnou variantou?}

Možným způsobem, jak přistupovat k oznamovací povinnosti, je v rámci hesla „pomáhající hlavně nesmí ohrozit sebe " hlásit policii všechna podezření na spáchání trestného činu. Je však takové jednání bezpečné? Pracovník v pomáhajících profesích a zejména psycholog jako zdravotnický pracovník bude často vázán povinností mlčenlivosti (viz $\S 51$ zákona č. 372/2011 Sb., o zdravotních službách). U dalších pracovníků v pomáhajících profesích je potřeba zkoumat, zda jim zákon povinnost mlčenlivosti ukládá (kromě výše uvedených zdravotníků, to budou i psychologové činní podle zákona o sociálních službách, viz $§ 100$ uvedeného zákona), nebo zda na sebe povinnost mlčenlivosti dobrovolně vzali v rámci kontraktu s klientem.

Porušení povinné mlčenlivosti se nedopustíme, pokud oznamujeme to, co požaduje zákon, naopak pokud oznamujeme nad rámec zákonné povinnosti, porušujeme svou povinnost mlčenlivosti. Uvedeným se pozice osob v pomáhajících profesích liší od řadových občanů, kteří mohou bez obav oznamovat každé jednání, o jehož trestnosti či pouhé závadnosti jsou přesvědčeni.

Z oznamovací povinnosti (nikoliv překazovací) jsou v $§ 368$ trestního zákoníku vyjmuti advokáti, duchovní a pro některé trestné činy osoby pomáhající obětem trestných činů. Ačkoliv se jejich postavení může na první pohled zdát záviděníhodné, tak při bližším zamyšlení zjišt'ujeme, že tyto profese jsou kvůli své mlčenlivosti zbaveny možnosti oznámit jakékoliv trestné jednání, o němž se od svého klienta dozví v souvislosti s výkonem své profese. Vyvstává zde otázka, zda by stejné vyjmutí z oznamovací povinnosti bylo vítané i pro pracovníky v pomáhající profesi, nebo zda existují situace, kdy je profesně i morálně správné, že pracovník v pomáhající profesi oznamuje policii jednání, o němž se dozvěděl od klienta.

Kromě toho, že za porušení povinnosti mlčenlivosti může být pracovníkovi v pomáhající profesi, který je zároveň zdravotníkem, uložena pokuta dle $\S 114$ odst. 1 písm. c). zákona č. 372/2011 Sb., o zdravotních službách ${ }^{14}$, tak v úvahu přichází vymáhání újmy, která oznámením oběti vznikla např. v podobě sekundární viktimizace, přičemž výše újmy, která porušením mlčenlivosti může vzniknout, je těžko odhadnutelná.

Pravděpodobně nejzávažnější sankci zde představuje možnost spáchat trestný čin neoprávněného nakládání s osobními údaji dle $\S 180$ odst. 2 trestního zákoníku (a to i z nedbalosti), za který lze uložit shodný trest jako za trestní čin neoznámení trestného činu. ${ }^{15}$

\footnotetext{
${ }^{14}$ Obdobně viz § 106 zákona č. 108/2006 Sb. o sociálních službách, který dopadá na psychology působící v sociálních službách.

${ }^{15}$ Je zde nutné zmínit, že skutková podstata trestného činu neoprávněného nakládání s osobními údaji také primárně nemírí na pracovníky v pomáhajících profesích, kteří činí trestní oznámení na základě informací od klientů, kriminalizace za takové jednání je velice nepravděpodobná.
} 
Neoprávněného nakládání s osobními údaji se dopustí ten, kdo poruší zákonem uloženou povinnost mlčenlivosti.

Konflikt mezi tím, že zákon vás o určitých situacích nutí mlčet a o jiných vás naopak nutí aktivně podávat hlášení, by byl jednoduše řešitelný, pokud by od sebe šly jasně a snadno rozlišit situace spojené $\mathrm{s}$ různým požadovaným chováním. V případě trestných činů tomu většinou tak není. Smyslem trestního řízení je zjistit, zda se určitý skutek stal, zda byl trestným činem a kdo jej spáchal, a tohoto pachatele potom trestně stíhat (Jelínek, 2013). Zákon staví pracovníky v pomáhajících profesích do pozice, kdy musí odhadnout výsledek celého trestního řízení na základě rozhovoru s jedním člověkem, což není jednoduchý úkol, protože často ani soudy po provedení obsáhlého dokazování nemají jasno v tom, zda k spáchání určitého trestného činu došlo, nebo zda se jednalo o trestný čin jiný, nebo zda jednání nebylo trestné vůbec.

To, že hranice mezi tím, co je trestným činem a co nikoliv, může být v konkrétním případě nejasná, vyplývá z judikatury vrcholných soudů české soudní soustavy, Nejvyšší soud má celou řadu judikátů tykajících se týrání dětí. Pokud v některých případech musí až dovolací soud určit, co týráním je a co nikoliv ${ }^{16}$, jak v takovém př́ípadě může správně rozhodnout právní laik s minimem informací?

Pracovník v pomáhající profesi je tak stavěn do pozice věštce, kdy má předem určit, jak soud nakonec kvalifikuje určité jednání, přičemž selhání těchto věšteckých schopností může být sankcionováno. Proto nemůžeme konstatovat, že by oznámení domnělého trestného činu vždy vedlo $k$ jednání v souladu s právem.

\section{Co dělat?}

Smyslem článku není navádět k nedodržování právních povinností, nechceme proto, aby za účelem vlastní ochrany pracovníci v pomáhajících profesích psali záznamy o tom, že klientům popisovaný trestný čin nevěří, pokud tomu tak není. Chceme minimalizovat roli strachu pomáhajícího pracovníka z vlastní kriminalizace v rozhodování o tom, zda trestný čin oznámit či neoznámit.

Hlavní doporučovanou zásadou je poučit klienta o tom, že oznamovací povinnost máme. Nicméně ještě za důležitější považujeme nutnost vyjasnit si, zda a za jakých okolností bychom k oznámení přistoupili. Situace, kdy se setkáváme s oznamovací povinností, můžeme rozdělit do čtyř skupin podle toho, zda jsme přesvědčeni o tom, zda oznamovací povinnost máme/nemáme, a zda je oznámení prospěšné/škodlivé pro zájmy klienta. Prospěšností zde myslíme to, zda jsme přesvědčeni, že oznámením dojde ke zlepšení situace klienta, což by měl být primární zájem psychologa ve zdravotnictví jako pracovníka v pomáhající profesi. $\mathrm{Z}$ úvah se nám zde poněkud vytrácí vůle klienta, který by měl stát v centru zájmu naší činnosti, pro níže řešené předpokládáme, že klient aktuálně trestný čin oznamovat nechce. Na základě uvedeného tedy můžeme rozlišit situaci, kdy jsme přesvědčeni:

- že oznamovací povinnost nemáme a pro klienta je oznámení dle nás škodlivé;

- že oznamovací povinnost máme a pro klienta je oznámení dle nás prospěšné;

- že oznamovací povinnost nemáme, ale pro klienta je oznámení dle nás prospěšné;

\footnotetext{
${ }^{16}$ Viz např. usnesení Nejvyššího soudu ze dne 17. 10. 2012, sp. zn. 8 Tdo 1168/2012.
} 
- že oznamovací povinnost máme, ale pro klienta je oznámení dle nás škodlivé.

V prvním uvedeném př́padě (povinnost: ne; prospěšnost: ne) bychom se oznámením nad rámec oznamovací povinnosti dopustili porušení povinnosti mlčenlivosti, a navíc bychom poškodili klienta, proto oznámení na místě není.

Ve druhém př́ípadě (povinnost: ano; prospěšnost: ano) je na místě vést klienta $\mathrm{k}$ tomu, aby trestný čin sám oznámil a nabídnout mu podporu v tomto procesu. Klient např. může učinit závazek o tom, že do př́štího setkání trestný čin oznámí. Pokud trestná činnost již netrvá, lze jen stěží takový postup pracovníka $\mathrm{v}$ pomáhající vnímat jako společensky škodlivý. Pokud klient k oznámení sám nepřistoupí, měl by aktivitu převzít pracovník v pomáhající profesi.

Ve třetím prrípadě (povinnost: ne; prospěšnost: ano) bychom oznámením trestného činu porušili povinnost mlčenlivosti a učinili důležité rozhodnutí za klienta, což pracovníkům v pomáhajících profesích nepřísluší. Pokud má pracovník v pomáhající profesi pocit, že má rozhodovat za klienta, tak překračuje své pravomoci a měl by v supervizi řešit otázku moci nad klientem (Guggenbühl-Craig, 2007).

Ve čtvrtém př́padě (povinnost: ne; prospěšnost: ano) stojíme před morálním dilematem (Bersoff, 2011), tedy před situací, kdy každé řešení povede k ohrožení důležitých hodnot. Bud'to trestný čin oznámíme a ohrozíme důvěru mezi námi a klientem, nebo neoznámíme a potencionálně ohrozíme své bezpečí a nevyhovíme autoritě. Pro morální dilema neexistuje obecné správné řešení, a proto zde nelze poskytnout obecnou radu, jak postupovat. Vhodné je přistoupit $\mathrm{k}$ důkladnému mapování situace, a to včetně informací o právních aspektech oznamovací povinnosti, které, jak doufáme, nabízí tento článek, a nerozhodovat se pod vlivem strachu.

Předkládané dělení situací vychází z toho, že jsme schopni vždy určit, že oznamovací povinnost máme, nebo nikoliv. Ale co když mám pochybnosti, nebo se pletu v posuzování trestného činu, který mám oznámit, anebo vůbec o oznamovací povinnosti nevím? Nevědomost o existenci oznamovací povinnosti je právním omylem a trestní odpovědnosti nás nezbavuje $^{17}$ (Šámal, 2012). Zajímavější je situace $\mathrm{v}$ př́ípadě, že se mýlíme v kvalifikaci trestného činu, jejž máme oznamovat, např. jsme přesvědčeni, že se jedná o zabití, ale ve skutečnosti je to vražda. Zde je potřeba rozlišit dva možné zdroje našeho omylu:

- $\quad$ bud'to máme správné informace a mýlíme se z důvodu, že nemáme dostatečné právní povědomí, nap̌r. jsme přesvědčeni, že každodenní bití dítěte není týráním, ale opakovaným lehkým ublížením na zdraví. Zde se opět jedná o omyl právní a trestní odpovědnost zde může být vyvozována,

- nebo si na základě informací, které z reality získáváme, vytváŕíme její chybný obraz. Např. věříme klientovi, že zde bylo dáno předchozí zavrženíhodné chování osoby, kterou usmrtil a že se tak jednalo o zabití a nikoliv o vraždu, později se ale ukáže, že klient lhal. Pokud je důvodem našeho omylu to, že máme zkreslené informace o realitě, což je v př́padě zprostředkovaného vnímání údajného trestného činu vysoce pravděpodobné, tak se dopouštíme omylu skutkového a nemůže nám tedy být přičítán úmysl trestný čin neoznámit a nemůže tak být vyvozena ani trestní odpovědnost.

Lze tak vyvodit, že pokud budeme znát své právem uložené povinnosti, tak se riziku trestní sankce za neoznámení trestného činu vyhneme, i pokud se budeme mýlit o realitě.

\footnotetext{
${ }^{17}$ Jinak by každý zloděj mohl argumentovat tím, že nevěděl, že nemůže krást.
} 
V závěru si dovolíme poněkud odlehčenou úvahu. Při laickém výkladu práva jsme všichni pachatelé trestného činu neoznámení trestného činu, a to navíc nenapravitelní recidivisté. Skutková podstata neoznámení trestného činu totiž nepracuje s tím, že oznamovat se nemusí to, co už policie ví. Po zhlédnutí večerních televizních novin bychom tak měli všichni neprodleně kontaktovat policii, protože jsme se důvěryhodně dozvěděli o spáchání celého množství trestných činů. Neoznámení trestného činu, o němž jsme se dozvěděli v televizních novinách, není trestným činem, protože toto jednání postrádá společenskou škodlivost a dle $\S$ 12 trestního zákoníku, tak zde nemůže být uplatňována trestní odpovědnost.

Prvním krokem, který bychom měli učinit, je tedy ptát se sám sebe, zda to, že neoznámíme určitý trestní čin, je společensky nebezpečným jednáním, které ohrožuje „,ájjem společnosti na boji s nejzávažnější kriminalitou odhalováním a postihem nejzávažnějších trestných činů a jejich pachatelï““ (Šámal, 2011 s. 367). Pokud si odpovíme záporně, neměli bychom mít obavy, že budeme za neoznámení trestného činu stíháni.

Kromě doporučení na individuální úrovni považujeme za vhodné, aby se o změnu situace zasadila i celá obec pracovníků $\mathrm{v}$ pomáhajících profesích. Zejména ty profese, které mají zákonem uloženou mlčenlivost, tančí na pomyslném (i když v praxi naštěstí naprosto ojedinělém) ostří nože mezi trestným činem neoznámení trestného činu a trestným činem neoprávněného nakládání s osobními údaji, je proto jejich zájmem, aby došlo k právnímu řešení této pro ně ohrožující situace.

\section{Literatura}

Bersoff, D. N. (2011). Ethical conflicts in psychology. 2. vyd. Washington: American Psychological Association.

Bořil, M. (2012). Soud potvrdil podmínku ženě, která nezastavila týrání malého Dominika. iDNES.cz, 28.6. http://brno.idnes.cz/soud-potvrdil-podminkuurednici-jez-nezabranila-tyranimaleho-dominika-z-brna-1xh-/brno-zpravy.aspx?c=A120628_122555_brno-zpravy_bor

ČTK (2009). Heparinové vraždy: souzení ředitele nemocnice bylo nezákonné. Lidovky, 12. 11. 2009. Dostupné z: http://www.lidovky.cz/heparinove-vrazdy-souzeni-reditele-nemocnicebylo-nezakonne-pt7-/zpravy-domov.aspx?c=A091112_163204_ln_domov_pks.

Guggenbühl-Craig, A. (2007). Nebezpečí moci v pomáhajících profesích. Praha: Portál. Jelínek, J. (2010). Trestní právo procesní. 3. vyd. Praha: Leges.

Mach, J. (2011). Znásilnění a pohlavní zneužití dítěte - hlásit či nehlásit? Dostupné z: http://www.zdravotnicke-pravo.cz/0007-znasilneni-a-pohlavni-zneuziti-ditete-hlasit-cinehlasit

Policie ČR (2017). Kriminalita. Dostupné z http://www.policie.cz/statistiky-kriminalita.aspx Sovová, O. (2011). Zdravotnická praxe a právo: praktická př́ručka. Praha: Leges.

Šámal, P. (2012). Trestní zákoník: komentář. 2. vyd. V Praze: C. H. Beck. 


\section{Soudní rozhodnutí}

Usnesení Nejvyššího soudu ze dne 17. 10. 2012, sp. zn. 8 Tdo 1168/2012

Usnesení Nejvyššího soudu ze dne 19. 6. 2013, sp. zn. 8 Tdo 554/2013

Usnesení Nejvyššího soudu ze dne 30. 9. 2003, sp. zn. 6 Tdo 1017/2003

Usnesení Ústavního soudu ze dne 10. 2. 2011 sp. zn. II ÚS 44/08

Rozhodnutí Vrchního soudu v Praze ze dne 13. 11. 1993, sp. zn. R 16/1994

\section{Právní předpisy}

Zákon č. 361/2000 Sb., o provozu na pozemních komunikacích

Zákon č. 133/ 1985 Sb., o požární ochraně

Zákon č. 372/2011 o zdravotních službách (ukládá v § 83 odst. 1 oznámit nález těla zemřelého mimo zdravotnické zařízení)

Zákon č. 40/2009 Sb., trestní zákoník

Zákon č. 108/2006 Sb. o sociálních službách

\section{O autorovi}

Mgr. et Mgr. Matěj Stříteský je doktorandem na Filozofické fakultě v Brně. Vystudoval práva a psychologii, pracuje pro Ligu lidských práv.

\section{Kontaktní údaje:}

Adresa: Filozofická fakulta MU v Brně, A. Novák 1, 60200 Brno

E-mail: matej.stritesky@1lp.cz 